\title{
IX.-Geological Sketch of the North-western Extremity of Sussex, and the adjoining Parts of Hants and Surrey.
}

By Roderick Impey MURCHISON, Esq. Sec. G.S., F.R.S., \&c. \&c.

[Read December 16th, 1825.]

I PROPOSE to illustrate in this memoir the order of superposition of the strata in that north-western part of Sussex which is bounded on the south by the chalk escarpment of the South-downs, and in those adjoining parts of Hampshire and Surrey which are bounded severally, on the west by the Alton chalk-hills, and on the north by the North-downs.

Having examined a portion of this country with my friend Dr. Fitton, I was encouraged by him to attempt an exact delineation of the whole, by colouring the Ordnance map according to geological formations *. This task being now accomplished, I beg to lay the result before the Geological Society, together with such illustrative specimens of the strata and their fossils as I have been able to collect in the course of last summer.

The formations of which this district is composed, begin to emerge from the superior strata at the northern extremity of the parish of Bentley in Hants, 6 miles north-east of Alton; and they range from thence to the south and east, until their escarpments are cut through by the Arun, which river I have chosen to make the limit of my present observations.

The chalk escarpments of the Alton hills and of the South-downs, converging towards Petersfield, are united at an acute angle in the parish of East Meon, 4 miles west of the former place; and within that angle the inferior strata are disposed conformably. Hence by assuming the Weald clay in the little valley of Harting Combe as the nucleus of the district, a regular succession is developed up to either chalk-range, and the breadth of each intermediate formation which mantles round the Weald clay, is shown by the map and section annexed.

The same order of superposition having been clearly established in the

* PI. XIV. is a sketch taken from the coloured copy of the Ordnance map alluded to in the text.

YOL. II.-SECOND SERIES. 
sections of the coast of the Isle of Wight*, my object is to point out the identity of this extensive inland tract, in which all the members of the series, from the chalk to the beds below the Weald clay, appear to be more largely and uninterruptedly displayed than in any other part of England. It is the more necessary to define accurately all the strata of this district, inasmuch as three of the formations have been hitherto described to be one range of green-sand; whereas the upper green-sand is divided from the lower, throughout the whole of this country, by a distinct and important breadth of Gault clay, of which the royal forest of Alice Holt forms the north-eastern portion.

The strata, therefore, the relations of which it is my object briefly to describe, commencing below the chalk in a descending series ; are,

\author{
1st. Firestone, or Upper Green-sand. \\ 2nd. Gault. \\ 3rd. Lower Green-sand. \\ 4th. Weald Clay. \\ 5th. Hastings or Iron Sand.
}

\title{
I. Firestone, or Upper Green-sand.
}

This formation, which lies immediately below the chalk, is provincially termed Malm-rock, and is known by that name alone in the counties of Hants and Sussex, throughout a range of 40 miles. Its geognostic position and the fossils it contains, prove it to be geologically identical with the upper green-sand or firestone of Merstham. The beds are nearly horizontal, or they dip at only a slight angle towards the chalk. The whole formation is peculiarly characterized by constituting terraces, which vary in breadth from a quarter of a mile to two and three miles, and which generally correspond to the sinuosities of the chalk hills. These terraces are covered by a tenacious grayish-white soil, celebrated for its abundant production of wheat. Quarries are to be seen in all the lanes which intersect this country; and in many places the sides of the roads, which by the rapid decomposition of the rock are worn into deep hollows, present sections from 20 to 30 feet deep. The harder beds are used for building ; and though the occurrence of firestone is not frequent, still that variety is seen in some places, at Selborne for instance, where it is employed in the construction of ovens.

The upper beds are the most cretaceous; but these sometimes pass into a grayish-blue compact limestone, which is of great thickness at Binsted and

* See Annals of Philosophy, 1824, New Series, vol. viii. 
Froyle in Hants, and at Sutton in Sussex :-occasionally a blue chert may be observed.

The inferior beds have a softer and more sandy character, particularly near their junction with the Gault.-The depth of the wells sunk in this stratum varies from 60 to 100 feet.

The fossil shells, though belonging to few species, are extremely numerous : they are usually much compressed; and the beds in which they abound being of a perishable quality, they are very fragile.

Those which I have collected are chiefly from Nursted and Buriton, Hants. -The following names were obligingly afforded me by Mr. Sowerby, who examined the specimens.

Ammonites rostratus.

Ammonites varians.

Pecten orbicularis.

Gryphæa vesiculosa.

Avicula. New species not yet figured.

Echino-spatagus. New species figured and named in the Icon. Sect. Foss. cent. 2da of König.

Fish :-fin of the Balistes?

Circular impressions and highly indurated cylindrical bodies, probably portions of stems of Alcyonia, are very frequent.-Of the above fossils, the Ammonites rostratus and the Pecten orbicularis are the most abundant and characteristic, the latter especially being often well preserved; and it is to be remarked that these two fossils occur in the same geological position in the Undercliff of the Isle of Wight.

The relations of the Malm-rock are no where better exhibited than in the vicinity of Binsted, Hants. The peninsular terrace upon which that village stands, is composed exclusively of this formation, which projecting nearly 3 miles beyond the Alton chalk-range from south-west to north-east, is surrounded at its base on three sides by the subjacent Gault. The Malm-rock is cut through by the river Wey, which thus separates the promontories of Binsted from those of Froyle and Bentley*.

There exists a remarkable analogy between this inland range, and that laid open in the coast-section of the Undercliff in the Isle of Wight. The Malmrock at Hawkley, like that of the Undercliff, forms a terrace terminated by a

* The Malm Rock of Sussex and Hants must be distinguished from the Maln Land of Surrey at the base of the North-downs, east of Box Hill ; the latter being an agricultural term for the black clay belonging to the Gault. 
mural escarpment, having its crest and base fringed with foliage, and resting upon a green talus of Gault. This base of clay after the wet winter of 1774 (see White's Hist. of Selborne, letter 45) gave way under the superincumbent pressure, occasioning the well-known Hawkley Slip, by which houses and barns were displaced or thrown down. The surface of the Gault was rent into fissures, and a large portion of the debris of the Malm-rock was ingulfed. The subsidence of the Gault between Luccombe and Bonchurch, in the Isle of Wight, has more recently occasioned a similar fall of the Undercliff.-It may be stated, as an inducement to the traveller to diverge from the high road into this district, that the deep and woody glens which intersect the escarpment of the Malm-rock, offer the most picturesque varieties of landscape.

\section{Gault.}

Below the range of the Malm-rock is seen a continuous breadth of Gault. This stratum is most clearly developed at the north-eastern angle of the district; where it forms the valley under Bentley and Binsted, and then rises into eminences which compose the forest of Alice Holt. The superior bed is commonly a brown or yellowish clay; but on penetrating a few feet, blue harsh clay is reached, which generally effervesces with acids, and appears to be of uniform character throughout, in the deepest sections. On the surface of Alice Holt there is frequently a diluvial covering of red and yellow flints, which in some places is from 12 to 14 feet thick; and where this occurs, water has been procured by sinking merely through this gravel; whilst in other parts, the subjacent blue clay has been penetrated to the depth of 40 feet unsuccessfully. Of the fossils of this formation $I$ have met most frequently with the Ammonites dentatus, at 6 or 8 feet below the surface. The junction of the Gault with the Lower Green-sand is clearly exposed at the south end of the village of Wracklesham, where the superior beds of the latter formation are similar to those, of which specimens have been brought up by boring through the Gault near Cambridge, and which are now in the museum of the Society.

The agricultural character of this clay is unvaried in its whole extent from Wracklesham near Guildford to the river Arun in Sussex. Its line is marked by the most fertile water meadows and the finest forest timber; thus presenting a green belt, which clearly defines and distinguishes it from the rich wheat land of the Nalm-rock above, and the arid expanse of the Lower Green-sand below.

\section{Lower Green-sand.}

The Lower Green-sand is the most extensive formation in this district, and presents an undulating and unequal surface. It rises from the valleys of Gault, 
and the adjoining Parts of Hants and Surrey.

and swells into hills, which increase in elevation as they recede from the incumbent strata, and finally attain a height equal to the most lofty points of chalk in the range of the South-downs.

The beds dip every where towards the chalk, but in the south-eastern part of the district more rapidly than in the north-western. They are inclined towards the Alton chalk-hills at an angle which is scarcely perceptible, and accordingly in that quarter are expanded over a more considerable extent of surface than towards the South-downs, where the dip frequently amounts to 10 or 15 degrees.

Woolmer Forest, Petersfield, Haslemere, Midhurst, and Petworth are in this formation.

The superior beds consist of quartzose grains combined with oxide of iron ; and they abound in veins of iron-stone, which are occasionally hollow and of large dimensions, at other times compact. The colour of the sands in this part of the formation is very varied : in some places, as near Rogate, deep sections occur of a pure white sand ; whilst in Woolmer Forest and at Frensham the mass is dark red, with many veins of contorted and cellular iron-stone.

A bed of calcareous grit appears to occur uniformly along the centre of this formation, and may be traced from Godalming through Headley, Lyss, Rogate, Stedham to Dean Farm near Petworth. At the latter place it is a compact blue limestone, and is extensively quarried for the roads; but in the former situations, the grit is a conglomerate of quartz grains and pebbles, bound together by a strong calcareous cement, and is called Bargate Stone*; -it is hard and durable, and has recently been burnt for lime.

Towards the lower part of the sands, gray and blue chert occurs, particularly at Iping Hammer-ponds, Brinksole Heath, \&c. \&c.

The lowest beds are marked by a great change of appearance;-green particles are now intimately mixed throughout the mass, and all the hills which immediately adjoin the valley of the Weald clay, afford a yellowish sandstone filled with green particles, which is used for building, and is the only bed of this formation west of the river Arun, which I have observed to contain fossils, or rather the casts of them + . These casts appear to be of Ammonites and Terebratulæ, but were not sufficiently perfect for Mr. Sowerby to distinguish the species.

* Mr. Greenough informs me that this calcareous grit extends eastward thoughout the same formation in Surrey and Kent, where also it is known by the name of Bargate Stone.

+ Parham Park is in this formation; but being of the river Arun, the consideration of the fossils found there is not now entered upon.-Those however which $I$ have seen from that place, are very unlike the casts to which I now allude. 
The best quarries of this rock are north of Midhurst, as at Dunner Hill, Pit's Hill, \&c. \&c.

It is worthy of remark that this formation, though not retentive of water, supports a vast number of small lakes or ponds. Those of Frensham, Woolmer Forest, Petersfield, Iping and Burton are examples.

The river Wey (the principal branch of which rises in the chalk at Alton from numerous and perennial springs), after flowing through the chalk, the Malm-rock and the Gault successively, has its course exclusively in this stratum for about 20 miles, until it turns to intersect the chalk-escarpment at Guildford. In like manner the Rother, or western branch of the river Arun, which rises in the chalk and flows over the intermediate formations, is in its subsequent course confined to these sands ; passing near Lyss, Petersfield, and Midhurst, to its junction with the main branch at Pulborough.

The depth of the wells in this formation increases with the rise of the hills. At Petersfield water is reached in 20 or 30 feet ; at Rake common, in 200 feet ; and in boring for water this summer at Petworth-house, near 400 feet of sand were passed through, when a blue clay was brought up which effervesced with acids.

Diluvial accumulations of chalk flints sometimes occur on the surface of these sands, as at Rogate Common, \&c. and several beds of such debris were cut through last summer near Trotton, in making the new road from Petersfield to Midhurst. Their presence on this stratum is worthy of remark, as I have never met with them on the subjacent formation of Weald clay.

\section{Weald Clay.}

The Weald clay, which is next in the series, forms at Harting Combe the nucleus of the western part of this district.-The line A B on the map, drawn from this point west-by-north and south-south-east, shows a section complete in all its members up to the chalk escarpment on either side.

The passage from the lower green-sand to the clay is well observed along the base of the hills which bound the valley on the south, where very thin beds of various-coloured clays alternate with soft dark green-sand. These striæ seem to mark the dip, which is at an angle of from 10 to 12 degrees.

The surface clay in the bottom of the valley is yellowish-brown in colour; but changes below to a deep red, and is then highly impregnated with oxide of iron.

The general form of the valley in this part of the Weald is peculiar, and the great inequality of its width is a striking feature in the geological map.

From its western angle and commencement at Harting Combe, little more 
and the adjoining Parts of Hants and Surrey.

of it is seen to the east, for 7 or 8 miles, than a narrow gorge, which is flanked, on the north, by the lofty hills of Blackdown, and on the south, by the corresponding ridge extending from Holder and Bexley hills to near Petworth. The valley is then suddenly expanded to three times its former breadth by the retirement at a right angle of the sand-escarpment of Blackdown and Haslemere.

In the extensive vale thus laid open the best specimens of the Sussex or Petworth marble are found. The disintegrated beds near the surface afford the characteristic Viviparæ in abundance, whilst in the more compact masses the Cypris Faba may also be discovered. The different localities of this marble are given in the annexed table of the order of superposition : but it may be remarked that the parish of Kirdford contains some of the largest and finest slabs.

Iron-ore is much disseminated through this formation, as well as through the inferior formation of Hastings or Iron Sand.-The Weald clay abounds in ancient iron-works, and their sites are still to be traced from near the junction of the lowest beds with the Hastings sand, up to the highest beds at the base of the lower green-sand. In the gorge of Harting Combe, at Lynch, Redford, \&c. \&c., the slag of the extinct furnaces is yet used as a material for repairing roads. These places are situated from 10 to 12 miles west of the outcrop of the iron-sand.

\section{Hastings or Iron Sand.}

This lowest formation of the vale of Sussex rises in gentle undulations immediately to the east of Kirdford in the parish of Wisborough Green, where, at Headfold-wood Common near Loxwood, its outline makes an angle, corresponding to that formed by the Weald clay and the superior strata.

Although these beds at their first emergence consist chiefly of clay, yet they differ essentially from the Weald clay in containing near the surface small flags of a slightly calcareous sand-stone, and beneath these, large tabular masses of a calcareous grit, which is very similar to certain beds of the Stammerham and Slinfold quarries west of Horsham. Unlike, however, to the latter, the calcareous grit-stone of Wishorough Green is based upon a deep mass of red ferruginous marly clay, and is only found in detached portions.

The Horsham beds have already been well described by Mr. Lyell, in a letter addressed to Mr. Mantell and read at the Geological Society, and have been examined by Mr. L. at Stammerham; but their extension to Skiff Common and Loxwood, from 9 to 10 miles west of that place, has not previously been noticed.

I have now the satisfaction of laying before the Society numerous fossil remains of large vertebrated animals from two localities at the extreme 


\section{Mr. R. I. Murchison on the North-western Extremity of Sussex,}

western angle of this formation, where the inhabitants have occasionally found similar remains for many years. Their occurrence to the eastward, however, appears to be very partial. In the extensive quarries of Stammerham I could only discover that one vertebra had been seen (apparently that of a tortoise); whilst in the intervening tract of 9 or 10 miles between that place and Loxwood, no analogous remains have been met with, although numerous quarries of the same tabular grit-stone are worked at Slinfold, Billingshurst, \&c. \&c.

The greater number of the bones now presented, were found at Headfoldwood Common, in 1824; they were situated about 5 feet below the surface : above them the mass was yellowish-brown clay, with micaceous sandstone occurring occasionally; and below the clay were large tabular masses of the calcareous grit. Immediately beneath this stone the bones were impacted in ferruginous and marly clay; under this were veins of blue clay, containing selenite.

The largest specimen proves to be a femur*. It measured, when entire, 3 feet 7 inches in length. (See Pl. XV. fig. 9.) One vertebra (No. 8) and many large fragments of bones were also found here.

Recently J. King, Esq. of Loxwood, has met with many more osseous remains imbedded in the clay north of his house, and about 3 feet from the surface. By his kindness I am now enabled to present a series of vertebræ and other specimens to the Society. (See PI. XV. fig. 1 to 7.)

Mr. Clift, of the College of Surgeons, obligingly examined these remains. He finds that they possess the striated texture of surface which characterizes the bones of fishes, crocodiles, and aquatic saurians; and that the thin wall or exterior crust, which covers an interior cancellated structure, further establishes his conclusion, that they have belonged to some great aquatic animal.

Having submitted the drawings and some of the specimens to Baron Cuvier for inspection, $I$ have been favoured by him with the following remarks. "I am inclined to believe," he observes, "that they are the remains of a new species of large saurian; since I am not acquainted with any thing similar to them amongst either recent or fossil reptiles : nevertheless, as Mr. Mantell has not yet found (that I am aware) the different parts of the skeleton of the Iguanodon, and since the formation in which these new bones occur, appears, from your account of it, to be a continuation of that of Tilgate Forest, I think it not impossible that some of these bones may have belonged to that animal. I can safely affirm that the vertebræ now submitted to me are not those of Plesiosaurus; but whether any of these remains did or did not belong to the

* This femur is in the possession of I. Napper, Esq., of Ifold, who politely sent it to the Geo. logical Society for inspection. 
Megalosaurus, the specimens of that animal in my possession are too few to enable me to decide. All that I can state is as follows. The vertebra No. 8, found near the great femur, does not appear to be of the same species with the others. No. 2 is probably a lumbar vertebra. No. 4 may be a sacrum. Nos. 1, 3, and 6, are certainly caudal vertebræ. No. 6, which (as you will observe) consists of two united into one, is remarkable for presenting an anchylosis of two caudal vertebræ: and No. 6 was disposed to become anchylosed to No. 3. I have just examined all my skeletons of reptiles, and have not found any analogous case, except when the tail has been broken; and then the bones become united by exostosis, which is not the case with these specimens. Hence it would seem, that this must have been an animal making such feeble use of the tail, that the caudal vertebræ were occasionally anchylosed together. No. 3 is one of the first caudal vertebræ, viz. of those which support the largest chevron-shaped bones; for the articular tubercles of these bones are very strongly marked upon it. No. 11 (not here figured) is the articular apophysis of a vertebra. Nos. 5 and 10 (not figured) are probably portions of ribs. As to No. 7, the rugosities of its two extremities, which evidently terminated upon cartilage, indicate that it did not belong to a limb; and it can therefore only have been either a false rib or a branch of the os hyoides."

Before receiving the preceding communication from Baron Cuvier, through the kind assistance of Mr. Mantell I had compared these remains with the bones from Tilgate Forest found in the same formation; but as no teeth or specimens sufficiently marked and peculiar have yet been met with at Loxwood, I was not able to establish any case of identity between the bones from these two localities.

The vertebræ are of a very uncommon form, being highly contracted in the middle with sharp angular sides; and of their two extremities, the one is nearly flat, the other concave : hence it appears probable that they are not referrible to the Iguanodon of Mr. Mantell, nor to any of the hitherto discovered saurians of Tilgate Forest.

In concluding the geological view of this district, I beg to observe, that if Loxwood be taken as a centre, a section to the south presents a similar succession of strata to that which is developed on either side of Harting Combe, with the addition in the former case of the iron-sand. The river Arun, in its course from the Weald, passes through the lower green-sand, the gault, the malm-rock, and the chalk of the South-downs ; whilst a section to the north, exposes principally the green-sand, between which and the chalk of the Hog's Back the intervening formations are reduced almost to imaginary lines.

VOL. II.-SECOND SERIES. 
106 Mr. R. I. Murchison on the North-western Extremity of Sussex,

\section{Appendix $I$.}

Order of Superposition.

\begin{tabular}{|c|c|c|}
\hline Formations. & Subdivisions and Varieties. & Localities. \\
\hline Chalk . . . . . & 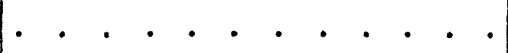 & South-downs, Alton Range, \&c. \\
\hline $\begin{array}{l}\text { A. Fire-stone or Upper } \\
\text { Green-sand, provin- } \\
\text { cially termed Malm- } \\
\text { rock. . . . . }\end{array}$ & 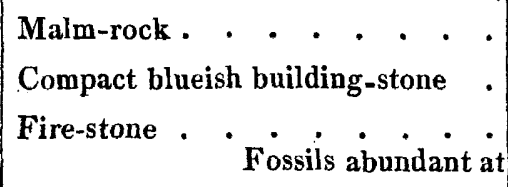 & 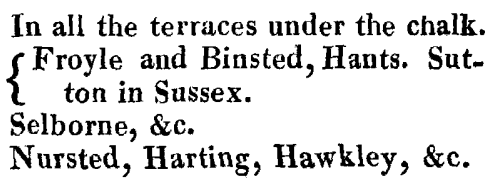 \\
\hline B. Gault . + , $\cdot$ & $\left.\begin{array}{l}\text { Upper beds stiff brown clay } \\
\text { Lower beds dark blue harsh clay } \\
\text { containing Ammonites, \&c. }\end{array}\right\}$ & $\begin{array}{l}\text { Alice Holt Forest, Steep, Down } \\
\text { Park, Elstead and Minsted } \\
\text { Marshes, \&c. }\end{array}$ \\
\hline $\begin{array}{l}\text { C. Lower green-sand, } \\
\text { Car-stone, or Shank- } \\
\text { lin Sand. . . . . }\end{array}$ & 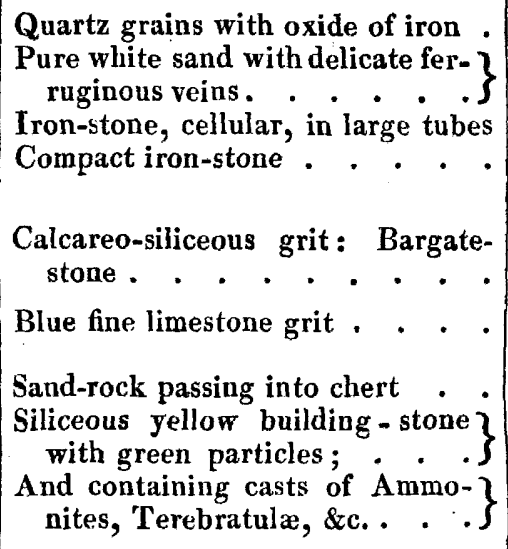 & $\begin{array}{l}\text { Petersfield, Turwick, \&c. } \\
\text { Sand.pits south of Rogate. } \\
\text { Road east of Cowdry Park. } \\
\text { Woolmer Forest, \&c. } \\
\left\{\begin{array}{l}\text { Hedley, Iyss, Trotton, Stedham, } \\
\text { and Half-way Bridge between } \\
\text { Midhurst and Petworth. }\end{array}\right. \\
\text { Dean Farm, Petworth. } \\
\text { Iping Ponds, Brinksole Heath, \&c. } \\
\text { Dunner Hill, Pit's Hill, and } \\
\text { Range north of Midhurst. }\end{array}$ \\
\hline D. Weald Clay . & $\left.\begin{array}{c}\text { Yellowish brown clay, red below } \\
\text { with argillaceous iron-ore } . . \\
\text { Yellowish brown clay, containing } \\
\text { compact Petworth marble . . }\end{array}\right\}$ & $\begin{array}{l}\text { Harting Combe, Redford, \&c. Ex- } \\
\text { tinct Iron furnaces, \&c. } \\
\text { Kirdford, Palfreys, Battlehurst } \\
\text { Glass-house, Spar Wood, \&c. }\end{array}$ \\
\hline $\begin{array}{l}\text { E. Hastings or Iron- } \\
\text { sand... }\end{array}$ & $\left.\begin{array}{l}\text { Calcareous sand-stone in clay, with } \\
\text { disintegrated Viviparæ: tabular } \\
\text { calcareous grit with bones of } \\
\text { large vertebrated animals } \\
\text { Deep red clay below with argil- } \\
\text { laceous iron-ore . } . \cdot \\
\text { Lowest bed: courses of blue clay } \\
\text { with Selenite. . . . . }\end{array}\right\}$ & $\begin{array}{l}\text { Headfold-wood Common, Lox- } \\
\text { wood, Wisborough Green, Skiff } \\
\text { Common, \&c. }\end{array}$ \\
\hline
\end{tabular}


and the adjoining Parts of Hants and Surrey.

\section{Appendix II.}

Quantity of Calcareous Matter in some of the Rocks mentioned in the preceding Paper.

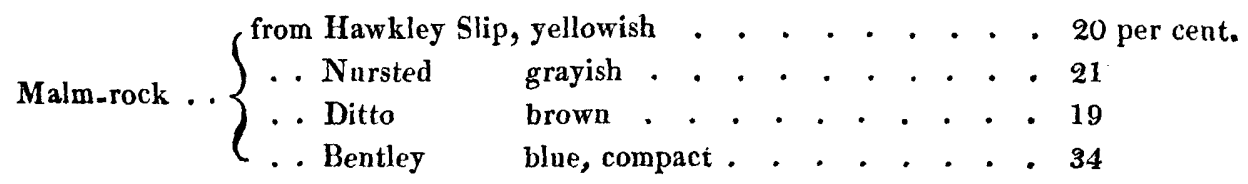

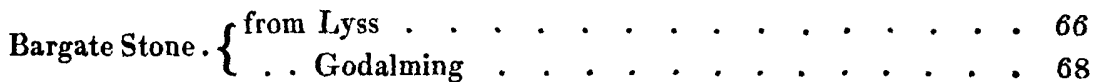

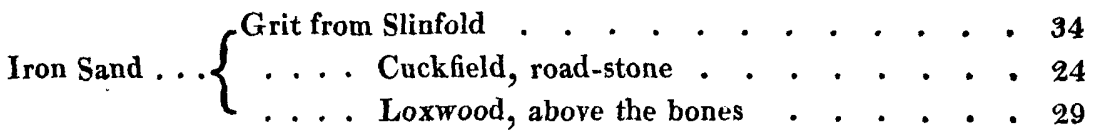




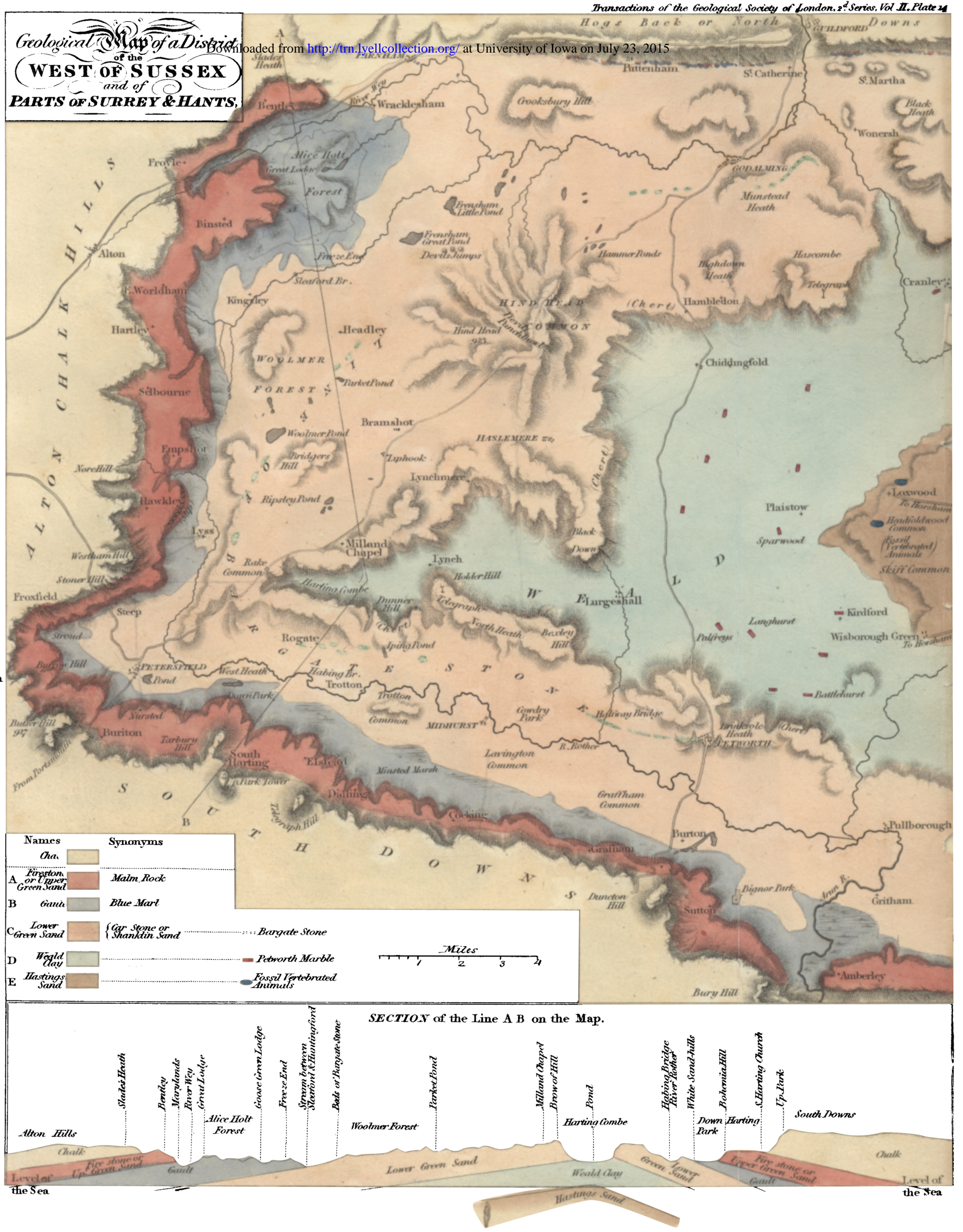


